Félix Armando Núñez

\title{
Canciones de la soledad invencible
}

LA CANCION DE LA VIDA

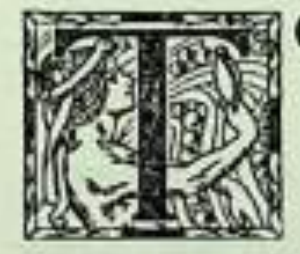

ODA la tierra está vibrando-con un rumor de colmenarlMartillo, arado, sierra y hacha-todo se mezcla en un cantar-y canto y sueño y pensamiento-se van hacia la luz solar!

Oh! corazón del mundo, que ama-la perfección y el ideal!:toda la tierra está vibrando-con un rumor de colmenar-entre el cordaje tembloroso-y áureo de la luz solar!

Mana alegría de los cielos,--estalla de alegria el mar:-itoda la vida es alegría!-iOh! la alegria de pensar, - de encontrar en la Luz Eterna-el tenue hilo elemental-que une las cosas más diversas-en una sencilla unidad.

Toda la tierra está vibrando-con un rumor de colmenar:- la tierra toda por la escala-del sol gozoso y del cantar-asciende más. asciende siempre-a la Belleza y al Ideal.

Ohl la alegría del trabajo-que. en la gozosa claridad,-hace latir la tierra henchida - con un rumor de colmenarl:- iLuz del pensamiento activo, - luz del amor y luz solarl: - Thacia la luz, toda la fierra-rompe en un diáfano cantarl

Oh! corazón del mundo, que ama-la perfección y el ideal!Martillo, arado y pensamiento-tienen un único compás,-y la canción del mundo en marcha,-la férvida canción total-por sobre las 
montañas-y el anhelo sin fin del mar,- - dice en su letra irresistible:isubamos más, subamos más!

CANCIÓN GOZOSA DE LA MASS TRISTE SOLEDAD

Oh! la nostalgia de las cosas bellas-que anhelé tanto y nunca fueron míasl-Oh! labios de mujer que me negaron-el sabor vehemente de la vida!

Oh! secreto del mundo, alma del agua-fugitiva palabra de las brisas,-suspiro de los valles! OI todo eso-que no pudo decir mi poesial

Ohl nudo que ata mi alma con la Tierral-Ohl atracción inefable y encendida-sobre mi corazón y mis sentidos-de lo que apenas saben mis pupilas!

El mundo nos sujeta en fuertes lazos-con atractivos que son nuestra dicha-y cada cosa bella que violamos-es una amarra menos a la Vida...

Ohl encanto de mi red infacta y trémula-en donde el Cosinos virginal palpital-Entre sus hilos musicales y áureos-la Tierra está como recién nacida.

Ohl sed nunca saciada que me logras-la palabra turbada de armonía!-Oh! divina nostalgia de las cosas:-imisterio de la vida no vivida!

Todo yo soy un ansia clamorosa, - un ansia de belleza, un ansia lírical-de frases balbucientes de ternura,- un ansia de vivir en nuevas vidas.

¿Qué bello nos parece lo que siempre-quisimos y se hurtó a nuestra codicia!-El ruiseñor sediento de la luna-quiebra su anhelo en claras melodías.

Oh! belleza de todo lo lejano,-maravilla del cielo, poesía-de los astros!... También está lejana-para mi corazón la propia vida...

Mas, la embriaguez del canto me resarce, $-y$ aunque la voz no suba estremecida, - mi corazón encuentra en la Belleza-la más vibrante y diáfana alegría. 
III

\section{LA CANCION DE LA LUZ}

¡Júbilo del sol matutino, - embriaguez de lírico azul! — La avasallante lumbrarada-pone a cantar mi juventud, - y estoy gozoso, tembloroso-loco de luz, sin otro amor-que el amor potente a la vida -y el amor divino del sol!

En sutil oleaje de oro-rompe, cantando, el viento Sur-la gloriosa marejada-imponderable de la luz!

Como una bandera gigante-se estremece fúlgido el azul, - y en el delirio luminoso,- - grito de gozo al Norte, al Sur,-hacia todos los horizontes-y más allá del hondo azul,-como si mi corazón ebriofuese el manantial de la luz!

\section{IV}

CANCIÓN DE LA SOLEDAD LLENA

Canté la soledad, y no sabía-que tú llenabas esta soledadcomo un perfume vago-como un blando susurro del pinar.

Busqué el hondo silencio, y no sabía-que me callaba para oirte más,- que derramé mi vaso-para que lo volvieses a llenar.

$\mathrm{Mi}$ alma era un estanque luminoso-en que subía un agua musical:-cuando estuvo colmada-me estremeci evocando tu mirar.

Busqué el hondo silencio, y no sabia-que me callaba para oirte más,-que sólo en tu palabra - se me iba a revelar la efernidad. 